\title{
Nursing Professional Education: Implications of Education for Transpersonal Care
}

\author{
Emanuelle Caires Dias Araújo Nunes ${ }^{1}$ \\ Luzia Wilma Santana da Silva² \\ Eulina Patricia Oliveira Ramos Pires ${ }^{3}$
}

This study identifies the perceptions of undergraduate nursing students concerning their education to provide transpersonal care. This qualitative study was conducted in four public universities in Bahia, Brazil with 16 seniors (non-probabilistic sampling) through semi-structured interviews, analyzed through the Collective Subject Discourse. The results expressed the students' feelings in the face of the challenge to provide transpersonal care; the psycho-cognitive competencies required by inter-subjective praxis; their perceptions concerning the curriculum in relation to the psycho-emotional dimension of being, untying critical knots; strategies suggested. The final reflections indicate the need to implement changes in the professional education of nurses in order to recover the humanistic view while preserving the scientific view. Undergraduate courses should develop an interactive methodology capable of supporting a more humane, sensitive and inter-subjective care praxis.

Descriptors: Nursing; Education, Nursing, Diploma Programs; Nursing Care; Education, Nursing.

\footnotetext{
${ }^{1}$ RN, Master's Student in Nursing, Universidade Estadual do Sudoeste da Bahia, Jequié, BA, Brazil. Scholarship holder of Coordenação de Aperfeiçoamento de Pessoal de Nível Superior (CAPES). E-mail: manoharaujo@ig.com.br.

2 RN, Ph.D. in Nursing, Adjunct Professor, Universidade Estadual do Sudoeste da Bahia, Jequié, BA, Brazil.

E-mail: luziawilma@yahoo.com.br.

${ }^{3}$ RN, Specialist in Nursing, Assistant Professor, Universidade Estadual do Sudoeste da Bahia, Jequié, BA, Brazil.

E-mail: eulinapires@gmail.com.
}

Corresponding Author:

Emanuelle Caires Dias Araújo Nunes

Rua São Pedro, 264

Bairro: Centro

CEP: 45015-200 Vitória da Conquista, BA, Brasil.

E-mail: manoharaujo@ig.com.br 


\section{O ensino superior de enfermagem: implicações da formação profissional para o cuidado transpessoal}

O estudo buscou conhecer as percepções de acadêmicos do curso de graduação em Enfermagem acerca de sua formação para o cuidado transpessoal. Trata-se de pesquisa qualitativa, realizada em quatro universidades públicas da Bahia, com 16 formandos (amostragem não probabilística), através de entrevista semiestruturada, analisada por meio do discurso do sujeito coletivo. Os resultados expressaram os sentimentos dos discentes diante do desafio do cuidado transpessoal, as habilidades psicocognitivas necessárias para a práxis intersubjetiva, as percepções acerca da grade curricular em relação à dimensão psicoemocional do ser e o desenovelando dos nós críticos - estratégias sugeridas. As reflexões finais apontam para a necessidade de implementar modificações na formação profissional do enfermeiro, de modo a resgatar o olhar humanístico junto ao científico. Sugere-se que os cursos de graduação desenvolvam metodologia interativa capaz de subsidiar práxis de cuidado mais humana, sensível e intersubjetiva.

Descritores: Enfermagem; Programas de Graduação em Enfermagem; Cuidados de Enfermagem; Educação em Enfermagem.

\section{La enseñanza superior de enfermería: implicaciones de la formación profesional para el cuidado transpersonal}

El estudio buscó conocer las percepciones de estudiantes del Curso de Graduación en Enfermería acerca de su formación para el cuidado transpersonal. Se trata de una investigación cualitativa realizada en cuatro Universidades Públicas de Bahía, con 16 estudiantes del último curso (muestreo no probabilístico), a través de entrevista semiestructurada, analizada por medio del Discurso del Sujeto Colectivo. Los resultados expresaron los sentimientos de los discentes delante del desafío del cuidado transpersonal; las habilidades psicocognitivas necesarias para la praxis intersubjetiva; las percepciones acerca del plan de estudios en relación a la dimensión psicoemocional del ser y el desatar de los nudos críticos - estrategias sugeridas. Las reflexiones finales apuntan para la necesidad de implementar modificaciones en la formación profesional del enfermero, de modo a rescatar la mirada humanística junto al científico. Se sugiere que los cursos de graduación desarrollen una metodología interactiva capaz de subsidiar una praxis de cuidado más humana, sensible e intersubjetiva.

Descriptores: Enfermería; Programas de Graduación en Enfermería; Atención de Enfermería; Educación en Enfermería.

\section{Introduction}

The proposal of this study originated during the development of a Master's thesis in Nursing and Health given the challenge faced by nurses in exercising care as an inter-subjective praxis in health. From the knowledge gained in this process of constructing/ reflecting, emerged concerns that include the evaluation of higher nursing education programs as they provide psycho-emotional training for the praxis of the nursing professional/caregiver.

Human care is considered in this study as the essence of the nursing praxis, developed in a procedural manner in the human experience and grasped as professional competence in the face of compromise with the human being in his/her integrality of body, mind and soul, embracing ethics, morality and esthetics, developers of a professional posture capable of contemplating the multiple dimensions of the human being from the transversality of scientific knowledge and the humanistic being.

The need for nursing professionals to have an education able to support the development of this transpersonal competence for human care has been 
largely discussed given the need to understand the human being in social, cultural, historical and psycho-emotional contexts, which demand nurses to approximate the integrality of being, through the development of psychocognitive abilities that connect the knowledge fields of anthropology, psychology, philosophy, sociology, and others, awakening their sensitivity - a characteristic of the human being - to perceive oneself and others in the context of their praxis.

In this context, the national curricular guidelines of the Undergraduate Nursing Program mandate that higher nursing education programs should give priority to the development of critical-reflexive humanistic skills and abilities, to the psychosocial dimensions of the human being, bestowing on their praxis a sense of social responsibility for the integral health of others and oneself (physical and mental self-care) seeking quality, efficiency, and problem-solving capability in the care of human lives ${ }^{(1)}$.

Contemporary nursing seeks to break with Cartesianism, to which it is still in submission, to elevate and value the subjective aspects in the professional relationship and human beings, both involved in the care process that involves personal experiences, meanings, values and different ways of being and coping with daily situations in the universe of relationships, which permeate the knowing-being-doing of care based on subjectivity.

However, the development of this inter-relationship in the care process is faced with limitations professionals have to deal with to expose their subjectivity and perceive and welcome the subjectivity of another. Scholars are unanimous in stating that fragmented higher nursing education programs based on instrumental competencies more than on emotional competencies, are co-responsible for the difficulty in working inter-subjectivity into the care praxis and also for the dichotomy existent between theory and practice ${ }^{(2-5)}$.

From this perspective, a study aiming to identify and analyze the perception and feelings of nursing students in relation to their education as a person/professional gathered reports indicating that holism exists only in theory, which reveals a web of feelings that involves the students, that is, the difficulty in acquiring practical experience $^{(3)}$.

In this context, the pedagogical education of the nursing professor required to meet the new educational demands of society is also discussed, indicating that it is not possible to educate generalist, critical and reflective nurses if nursing professors do not have an appropriate education themselves ${ }^{(6)}$. Hence, it appears that the nursing praxis should transcend technical action toward a responsible action for the mutual growth both of those who care and those who are cared for. Training individuals to practice transpersonal care requires one to recover the meaning of human existence, which will only be achieved when felt and experienced as love and respect for the dignity of life and sensitivity to one's existence $^{(7)}$.

The relevance of this study lies in the opportunity to experience higher nursing education in relation to the development of psycho-affective and cognitive skills for the practice of transpersonal care. The scarcity of studies addressing this theme on the searched databases reinforces and is evidence for its importance. Therefore, this is a problem to be unveiled, and the study's objective is to identify the perceptions of nursing undergraduate students concerning their education in the exercise of transpersonal care.

\section{Method}

This is a descriptive study with qualitative approach the setting of which comprised four Public Higher Education Institutions in the state of Bahia, Brazil: Bahia State University (UNEB), State University of Feira de Santana (UEFS), State University of Santa Cruz (UESC) and State University of Southeast Bahia (UESB) located in Salvador, Feira de Santana, Ilhéus and Jequié respectively, Bahia, Brazil. The study's participants $\square$ were senior undergraduate nursing students from the mentioned universities, selected through nonprobabilistic sampling. The sample was composed of 16 individuals: 13 women and three men between 20 and 30 years of age. The sample was delimited by reaching data saturation. Ethical aspects related to research involving human subjects were complied with according to Resolution 196/96 ${ }^{(8)}$. The Ethics Research Committee at UESB approved the study (protocol № 184/2009). Data were collected between March and April 2010 after participants signed free and informed consent forms. Semi-structured interviews were carried out guided by the following questions: 'Do you feel able to deal with/ care for the psycho-emotional dimension of people under your care responsibility? Why?'; 'What competencies/ abilities do a nursing student needs to develop in order to achieve a care practice that addresses patients in their bio-psycho-socio-cultural-environmental-ecologicalspiritual totality?'; 'What is your perception concerning the curricular structure of the nursing program in terms 
of professional education to enable students to practice inter-subjective care?'; and 'What educational strategy do you suggest in the academic sphere to enable students to practice transpersonal care?'. The analysis was developed using Collective Subject Discourse highlighting key-expressions (KE) described by the central idea ( $\mathrm{CI}$ ) and grouped to construct the collective subject discourse (CSD) ${ }^{(9)}$.

\section{Results}

The CSD based on interviews held with 16 students, four from each institution, are presented as follow. Four axes emerged from the analysis.

$1^{\text {st }}$ axis - feelings of students in the face of the challenge of providing transpersonal care - originated four CI.

CI - A1: I feel prepared given my experience extracurricular practice and community services

My experience acquired during the extracurricular training and in community service has made me feel more secure to be involved in these issues (psycho-emotional). I feel more prepared from having had this contact, which taught me to deal with different situations. I received a scholarship for two years and worked a lot and got familiar with the context of care; each semester we do a little thing and summing up. You become more sensitive and perceive that patients are not only biological beings, but also social and emotional beings. It is different from students who only pass through the university and others who have experience; students in community services acquire a different perspective. (CSD - A1)

CI - B1: I feel prepared by the essence - history of life

I'm kind of experienced but I didn't acquire it during my undergraduate studies only. It comes from my family background, support I've had to cope with situations and that helps me to psycho-emotionally intervene with patients. We always try to deal with these issues and when you get there, during professional practice, we see ourselves in the other person and start to question, reflect and change. I'm willing to change concepts, banish preconceived ideas and rethink myself. (CSD -B1)

CI - C1: I do not feel prepared - education focuses on objectivity/science

Look, sincerely I don't feel able, mature enough to meet these psycho-emotional needs because, throughout the program, we've were concerned with the technical issues and never emphasized much this psycho-emotional aspect. When an isolated course was proposed to work on this issue, the students themselves found it weird because we weren't used to subjectivity. During practice, care is directed to the physiological, pathological, pharmacological aspects and not to the emotional part of people. Then we feel we can't meet the psycho-emotional needs of people; we realize that people need to vent, to talk cry, have some support. There are some groups: rape, people with cancer, HIV positive patients, to whom I don't know what to talk about, how to act with or behave. (CSD -C1)

CI -D1: I have feelings of insecurity - who cares for me?

I feel a bit insecure, we aren't prepared to deal with death and suffering. We aren't prepared to take care of ourselves. Many students get psychologically shaken, sometimes we don't have family around, get a little loose, get desperate. We also have limits as caregivers, we have to be careful not to absorb others' suffering, we have to be psychologically, spiritually, and emotionally prepared; nurses have to be ok with themselves in order to help others. (CSD - D)

The first axis presented antagonistic discourses that involved two themes: those who feel apt and those who feel inept; both groups presented more than one testimony, which were complementary. These individuals felt insecure in relation to the ability of academic education to enable them to establish bonds and develop psycho-emotional competencies. On the other side, what provides them some support to approach these issues comes from their family-emotional structure and their experiences in the community acquired during supervised training and extracurricular activities, which confirms the importance of such experiences.

Many difficulties are encountered in the performance of nursing interventions in the emotional, perceptive, and relational spheres that accrue from an education focused on deviation from a healthy state. Instrumental care, however objective it may be, interferes in the nurses' emotions, perceptions, and feelings, and it is important to consider the conflict between the positivist/ realist paradigm and the new becomings that emerge from the complexity of nursing care (know how to touch, listen, smell, utilize proprioception, intuition and subjectivity)(10).

Beginning in the 1970s and the 1980s, the need for nursing professionals to consider human needs other than those originating in the physical sphere was already entering theoretical awareness. The most important thing for patients and their families is that caregivers be available to them; then, in the second place, they expect professionals to have technicalscientific competence. Therefore, caregivers need to develop a relationship of interest with the person with whom they are interacting ${ }^{(11)}$. 
The need to rethink the education of nursing students is urgent so that these professionals do not only consider physical aspects but also social, cultural, environmental and affective aspects. Additionally, they should reflect upon the processes of family and educational formation in the transformation of critical-reflective individuals, capable of evaluating their existence in the world and their importance in the human collective, and nurses on their posture/care praxis(5). Cognitivism considers that every intelligent action, in this case the professional praxis, is born in the subject's intellectual structure, who in turn perceives reality from the relationships between cognitive aspects and concepts and meanings they have given their own historical background ${ }^{(12)}$.

The personal/professional educational process integrates education and is first developed within the family to then aggregate values to the construction of the being in his/her conception of a professional subject. Therefore, it involves work, teaching, research, community service, socio-cultural movements, that is, every sort of human relationship established in society, especially in the academic sphere. It is clear that human beings only value and absorb knowledge if their experiences indicate the need for such knowledge, which happens when past interactions emerge when one looks, touches, lives a new reality/knowledge.

$2^{\text {nd }}$ axis - psycho-cognitive abilities required for the inter-subjectivity praxis - originated two CI.

CI - A2: Inter-subjective bonds - I see myself in another person and get involved in his/her context to provide care

When we get sick, when we face some problem, that is when we really realize how important it is, this psycho-emotional care. So, when you manage to make this connection, when you put yourself in somebody else's shoes, there's identification, empathy, as if the other person were somebody from your family, you try to provide a more humanized care. You manage to contextualize, to know the factors that are interfering in that disease, such as family, life habits, cultural issues, the values of each person. That person has a history of life; she doesn't come out of the blue and appears in the hospital or the primary care unit, she's included in an environment. Many people used to say, in the past, that professionals shouldn't get involved in family history, but for me, professionals need to get involved, for sure. There's no way, you can't manage to be completely impartial. We're human beings and you can't separate these things. There are moments you get involved, the patient makes you cry because of his history, and there're times you get happy with his victories. (CSD - A2)

CI - B2: Therapeutic communication - developing sensitivity to perceive and welcome another

The professional needs to be communicative, attentive, be respectful of human beings, be sensitive and be committed to care for people in the most human manner possible. It is not only visiting the patient, but you have to develop active listening to perceive explicit (verbally communicated) and silent (not verbally communicated) needs, know how to touch and how to listen, many physiological problems are emotionally-based, you talk, dialog, the pressure goes down, the head stops aching. (CSD-B2)

The second axis refers to psycho-cognitive skills noted by the students as essential to care for a human being in a multidimensional manner, meeting his/ her transpersonal needs. Empathy and compassion accompanied by action, communication and devotion represent their ideal profile.

This understanding refers back to the origin of nursing based on sensitivity, understanding and the essence of care. The profession has currently been destitute of its genuine meaning; rationality has given priority to technique to the detriment of the human being. Nursing has been devoid of meaning and is filled with obscure conflicts, wrapped in enchantment and disenchantment, anxiety and joy, hits and misses, few certainties and many doubts in the search for meanings of 'being caregiver subject'(13). Patients have the right to access information to support more autonomous decisions that culminate in the exercise of their citizenship in relation to their own health ${ }^{(4)}$, which is only possible if they master communicative-dialogical and emancipating abilities ${ }^{(14)}$. Unfortunately, few nurses are prepared to deal with soft-relational technologies such as welcoming, bonds and sensitive listening.

Caregivers should also preserve themselves during professional activities, taking care of themselves as an essential condition to acknowledge the patient as a human being, who as him/herself has limitations, potentialities and difficulties. This is possible because both are alike; human beings have the ability to see themselves reflected in another, in another person's reactions, a fact that confers the highest degree of human quality ${ }^{(15)}$.

$3^{\text {rd }}$ axis: perceptions concerning the curriculum content in relation to the psycho-emotional dimension - originated two CI.

CI - A3: dichotomy theory versus practice

A dichotomy between theory and practice was observed throughout the program. A lot is discussed about inter-subjective care in theory but only technique is focused in practice: passing a probe, giving a shot. Even the Ministry establishes policies 
addressing integrality, equity, all principles to care for the human being in a global manner and all, only that in practice it doesn't happen this way. We don't experience, don't learn how to develop such care. (CSD-A3)

CI - B3: fragmentation of content - how to assemble the puzzle?

The curriculum is very outdated, we perceive the fragmentation of the courses, of knowledge. When we get to the management we get a little bit from each course; a lot is missing. There was no interdisciplinary content, no interaction between the courses. Collective and Hospital Care, we think that these are different things, only when you build up knowledge, when you're close to becoming a professional is it that you start to associate these two things and realize this is a network, the curriculum has to be more dynamic, content has to be interconnected. (CSD - B3)

The $3^{\text {rd }}$ axis shows the fragility and deficiency of higher nursing education. The fragmentation seen during nursing education has considerably harmed the education of caregivers, who face difficulties integrating their actions to reach the subject of their praxis and end up conforming to the system of service production.

One has to go beyond the mechanistic view of the medicine of organs toward a vitalistic view of a living body, a dimension regarding the sensitivity of care that enhances subjectivity. Hence, care becomes a transforming action through critical education, concepts and actions allied with emotions experienced in the process. Praxis that becomes a challenge that evidently implies self-knowledge in relation to attitudes, desires, and aspirations, which allow the emergence of a sensitive approach to know and practice care ${ }^{(16)}$. Each professional needs to recover 'his/her own sensitivity' to establish integral and inter-subjective human relationships ${ }^{(17)}$.

A study similar to this gathered reports based on the students' practical experience indicating that the principle of integrality, even though strongly disseminated, is little applied in the education of nurses when it comes to self-care. It highlights the importance of professors in guiding this process, who oftentimes forget to "humanize" their relationships with students, denying them the opportunity to experience the discourse they defend in theory, distancing what is taught from what is experienced, contributing to the incorporation of this dichotomized thought into professional practice ${ }^{(18)}$.

The need to overcome the Cartesian paradigm is organized into seven types of knowledge necessary to education in the future: overcome errors; knowledge of relevant principles; teaching related to the human condition; the context of earthly identity; understanding; coping with uncertainty; and ethics ${ }^{(19)}$. The interconnection of these different types of knowledge reveals the importance of working under the axis 'intellect-affection' integrating at all times subjective and objective dimensions in the act of teaching and caring. Hence, "a divided, compartmentalized, mechanicist, disjunctive and reductionist intelligence ruptures the complex aspect of the world in disjunctive fragments, breaks up problems, separates what is joined, turns the multidimensional into one-dimensional. It is a myopic intelligence $[\ldots]$ it destroys possibilities of understanding and reflection while they are still embryonic ${ }^{(18) "}$

In this direction, science starts to require a crosssectional view, seeking to see what is occult to perceive that where one expects to find simple things, one finds an infinite complexity where the whole is not equal to the sum of the parts ${ }^{(20)}$. The disciplines are parts that need to inter-relate and be diluted in a dynamic whole - interdisciplinarity ${ }^{(21)}$, and should be sought in the higher education of nurses to provide an integrative and transpersonal education.

Therefore, Jean Watson's theory of transpersonal care is required. It evokes the totality of a paradigm expanded to the future, which not only considers the scientific aspects of the nursing profession but also the social mission it has with humanity to care/heal through a human consciousness that contemplates the amplitude of such care. The pedagogical role of nurses in this transpersonal care is very clear. The fact that these professionals often are not properly prepared to play such role, nor receive systematic methodology to perform the role of teaching/facilitating/constructing/ caring is unfortunate. Additionally, the inter-subjectivity and relational aspects of the process are not always explicit, which hinders the educational process, including the subsequent education of future nurses, culminating in a teaching process that transmits information on health but leaves at the margin the complexity of transpersonal aspects $^{(22)}$

Hence, nursing education needs to include generalization, differentiation, acknowledgement, intersubjectivity and interdisciplinary aspects. It is about intellectual development, a slow and gradual process, in which academic education plays an important role in the achievement of this being.

$4^{\text {th }}$ axis unfolds critical knots - suggested strategies originated four $\mathrm{CI}$.

CI - A4: the professor (my measuring stick) education/qualification of the faculty members

Integral care has to be put into practice, but for that, a 
lot of things have to change. It has to happen to professors first. Professors have to pay attention and guide us, directing our view. We look up to them, they're our masters, and their practice encourages us, whether they like it or not. We're their reflexes and they're a mirror to us, but few of them work on this trans-personality issue, this emotional thing. The professors need to be qualified for that, they have to have it so they can pass it to us. When we have a professor who has this subjective view, experience, we feel more secure to work this with patients because professors show us how to do it. I realize these professors don't have this psycho-emotional experience. There were professors who didn't have practical experience, only theory, so it was something, empirical. They said how it should be but didn't show it in practice. (CSD-A4)

CI - B4: the courses - the quest for subjectivity

There are courses that talk about death, they address some concepts but do not psychologically prepare us to work with these issues and to cope with loss. Psychology is taught in the first semester and we're still too lost in the program, don't know how we're going to use it. It doesn't specifically address psychology in nursing because the professor is a psychologist. It'd be great if a nurse administered it so we'd be able to link it to our practice. We have too much theory, but it'd be good to practice these principles, the subjectivity and empathy issues, we should have a course that put into practice these issue of talking to people. There should be a course only to prepare students to approach patients, to communicate, to care for this psycho-emotional dimension. There're people who get to a certain point in the program and still don't feel prepared to face the reality of nursing practice; it considerably affects one's professional life. (CSD-B4)

CI - C4: the methodology - and interdisciplinary activity

Curricular reform should develop a better methodological practice. This traditional pedagogical model is very vertical. The professor ends up in a mold; he has to use a strategy to provoke not defend, provoke students so when they become professionals they are more focused on the transpersonal aspect, use active methodologies from the beginning of the program, because it gives one the opportunity to expose knowledge and construct new knowledge. It'd be also interesting to have access to patients with a lower demand of technical care so you could value a bit more this psycho-emotional-social aspect. When we get a complicated patient that requires many technical procedures, we tend to perform our duties and forget the transpersonal aspect. (CSD-C4)

CI - D4: the evaluation - looking at the student as a whole who wants to be polished

The evaluation process should be more trans-personal. You shouldn't be evaluated in certain aspects, but rather in the totality of your practice. There are supervised training programs in which: you spend the entire period and only socialize the last week, then you expose your difficulties and don't have time to work on them. The professor grades you, doesn't tell you why, you don't know what you have to fix. You go to another supervised training and the same mistakes go from one semester to the next, something that you could have a chance to improve. In practice, you don't manage to look at the patient as a human being. We use patients a lot in the sense that they are the targets of care, not for being cared for, but for our learning. At that point, this individual is the equivalent of that dummy we have at the university, you apply the bandages, administer medication, shower, the professor demands. We are very concerned about being evaluated, which harms communication, there is no give and take, receptor and transmitter. You're the owner of knowledge, you go there, do what you have to do and that's it, just to be evaluated by the professor (CSD-D4)

The $4^{\text {th }}$ axis comprises the suggestions brought by the students and addresses the spheres 'professors', 'course', 'methodology', and 'evaluation', which contribute to the unfolding of the questions proposed by this study. Breaking paradigms of educators who were educated in the traditional model is one of the greatest difficulties found related to flexibilization, valorization of the ethical-humanist dimension and interdisciplinary approach, principles that corroborate a pedagogical practice centered on totality ${ }^{(18)}$.

Therefore, an innovating pedagogical practice is essential and represents a challenge that opens up new horizons and possibilities of transformation. Collective and democratic participation is essential in the transformation achieved by all those who compose this teaching-learning network. Therefore, active methodologies enable a dialogical reflection capable of acknowledging the context and new perspectives to reconstruct new paths to integrate body and soul, theory and practice, teaching and learning, reason and emotion, science and faith, competence and lovingness ${ }^{(23)}$.

To achieve this educational praxis one needs to "reform thinking" in order to acknowledge the context, the global, the multidimensional, the inter-relation of whole/parts inherent to any-individual or collectiveliving system, especially at the point of learn-to-beto-do, the nursing professional praxis(19). Learning represents a re-adaptation of the cognitive structure of individuals, based on an assimilative scheme that involves: repetition, generalization, and differentiationrecognition(12).

From this perspective, the transpersonal teachinglearning process involves the educator's ability to work/ 
develop human psycho-cognitive skills involving thought, immediacy, humor and a relationship with the world, making a connection with other perceptions, feelings, concerns and knowledge that enable nurses to practice transpersonal care ${ }^{(22)}$.

Therefore, the structure of undergraduate nursing programs should ensure "[...] pedagogical strategies that link knowledge; know-how-to-do and living together, aiming to develop learning to learn, learning to be, learning to do, learning to live together and learning to know $[\ldots]^{\prime \prime(1)}$. That is, in light of our understanding, learning to be a transpersonal subject opens one up to the multidimensionality of different types of knowledge to achieve human relationships in care.

Hence, professional education pervades the personal being who develops to the point of aggregating values to the construction of his/her conception of professional subject, involving work, teaching, research, social and cultural movements, that is, human relationships established among complex and singular individuals with or without educational purposes in the society. Therefore, when contemplating professional education one needs to contemplate its amplitude to understand that every educational action should presuppose an interpretation that can permeate the context of the students' 'external reality', which will enable them to make a connection between what is underlying the individual's system of meanings. This cognitive organization represents the totality that composes the multidimensional being, who possesses inter-relational elements that need to be welcomed in the teaching-learning process.

Therefore, the social experiential world is inserted into the academic experiential world, which represents spaces of inter-relational recursive knowledge that influences the personal cognitive development of each being. Hence, the teaching-learning process in guiding the contextuality of the complexity of the being will guide the development of subjects capable of constructing, developing more sensitive, creative and compassionate human attitudes.

\section{Conclusion}

This study revealed the need for a new way of thinking about and acting out the teaching-learning process in nursing and the re-signification of the pedagogical education of nursing professionals to meet the educational requirements of educating caregivers within a discourse and set of actions close to theory and practice that enables them to exercise citizenship, ethics and politics, care in society: integral, universal, fair, individualized, transpersonal and that enables individuals to establish bonds.

We propose that faculty members should provide a more complete and interdisciplinary education to students, integrating self-knowledge, spirituality and resilience in the face of maturational processes to enable them to provide comprehensive human care bio-psycho-social and spiritual.

We suggest the inclusion of a new course in the curriculum of nursing undergraduate programs that enables the academic development of interactional, inter-subjective competencies with the subjects of nurses' care, their families and communities. For that, we propose the humanistic focus to go beyond the theoretical approach already existent in our education, including the exercise of inter-subjective care involving techniques such as therapeutic listening, music therapy, therapeutic touch, home care and the sensitivity of the nurse caregiver.

\section{References}

1. Ministério da Educação. Secretaria de Educação Superior. Diretrizes Curriculares Nacionais dos Cursos de Graduação em Enfermagem, Medicina e Nutrição. Diário Oficial da União de 3/10/2001, Seção 1E, p. 131. Brasília, DF; 2001. p.7. [acesso 25 set 2009]. Disponível em: http://portal.mec.gov.br/dmdocuments/ces1133.pdf 2. Corrêa AK, Sales CA, Soares L. A família do paciente internado em terapia intensiva: concepções do enfermeiro, Maringá, [internet] 2002; [acesso 11 julho 2008]; 24(3):811-8. Disponível em: http://www. ppg.uem.br/Docs/ctf/Saude/2002/23_Adriana\%20 Correa_A\%20familia\%20do_065_02.pdf.

3. Esperidiao E, Munari DB. Holismo só na teoria: a trama de sentimentos do acadêmico de enfermagem sobre sua formação. Rev Esc Enferm USP. 2004; [acesso 28 set 2009]; 38(3): 332-40. Disponível em: http://www. scielo.br/scielo.php?script $=$ sci_arttext $\&$ pid $=$ S0080 $62342004000300012 \& \mathrm{lng}=$ en\&nrm $=$ iso

4. Zoboli ELCP. Enfermeiros e usuários do Programa Saúde da Família: contribuições da bioética para reorientar esta relação profissional. Acta Paul Enferm. [internet] 2007; [acesso 08 abril 2009]. 20(3):316-20. Disponível em: http://www.scielo.br/pdf/ape/v20n3/ pt_a12v20n3.pdf

5. Oliveira WIA, Amorim RC. A morte e o morrer no processo de formação do enfermeiro. Rev Gaúch Enferm. 2008;2(3)191-8. 
6. Rodrigues MTP, Mendes Sobrinho JAC. Enfermeiro professor: um diálogo com a formação pedagógica. Rev Bras. Enferm. 60(4):456-459, jul.-ago. 2007.

7. Waldow VR. Cuidado humano - o resgate necessário. Porto Alegre (RS): Sagra Luzzatto; 1998.

8. Ministério da Saúde (BR). Conselho Nacional de Saúde. Resolução n 196/96 sobre pesquisa envolvendo seres humanos. Bioética 1996;4 supl (2):15-25.

9. Lefrève $F$, Lefrève AMC. O discurso do sujeito coletivo: Um novo enfoque em pesquisa qualitativa. $2^{a}$ ed. Caxias do Sul: Educs; 2005.

10. Teixeira ER. A crítica e a sensibilidade no processo de cuidar na enfermagem. Esc Anna Nery. [internet] 2004; [acesso 10 set 2009]; 8(3):361-9. Disponível em: http://www.eean.ufrj.br/REVISTA_ENF/2004_ vol08/2004_vol08n03DEZEMBRO.pdf

11. Nascimento ERP, Trentini M. O cuidado de enfermagem na unidade de terapia intensiva (UTI): teoria humanística de Paterson e Zderad. Rev. Latino-Am. Enfermagem [internet] Ribeirão Preto, 2004; [acesso: 05 ago 2009] 12(2):250-7. Disponível em: <http://www. scielo.br/scielo.php?script $=$ sci_arttext\&pid $=$ S0104$11692004000200015 \&$ lng $=$ en\&nrm =iso

12. Flavell JH. A psicologia do desenvolvimento de Jean Piaget. 5.ed. São Paulo: Pioneira; 1996.

13. Girondi JBR, Hames MLC. O cuidar institucional da enfermagem na lógica da pós-modernidade. Acta Paul Enferm. [internet] São Paulo, 2007; [acesso: 31 março 2009] 20(3): 368-72. Disponível em: http://www. scielo.br/scielo.php?script $=$ sci_arttext\&pid $=$ S010321002007000300021\&lng=pt\&nrm =iso

14. Watzlawick $P$, Beavin HB, Jackson DD. Pragmática da comunicação humana - Um estudo dos padrões patologias e paradoxos da interação. São Paulo: Cultrize; 1967.

15. Pinho LB, Santos SMA. Fragilidades e potencialidades no processo de humanização do atendimento na unidade de terapia intensiva: um estudo qualitativo de abordagem dialética. Online Braz J Nurs. [internet] 2007; [acesso: 11 julho 2008]; 6(1). Disponível em: http://www.uff.br/objnursing/index.php/nursing/ article/viewArticle/853/178

16. Teixeira ER. A questão de eros na filosofia do cuidado com o corpo. Texto Contexto Enferm. 2006; 15(3): 18692. doi: 10.1590/S0104-07072006000500023.

17. Erdmann AL, Sousa FGM, Backes DS, Mello ALSF. Construindo um modelo de sistema de cuidados. Acta Paul Enferm. [internet] São Paulo, 2007; [acesso 07 abril 2009]. 20(2): 180-5. Disponível em: http://www. scielo.br/scielo.php?script $=$ sci_arttext\&pid $=$ S0103$21002007000200011 \& \mathrm{lng}=\mathrm{en} \& \mathrm{nrm}=$ iso
18. Espiridião E, Munari DB. A formação integral dos profissionais de saúde: possibilidades para a humanização da assistência. Formação profissional: possibilidades para a humanização da assistência. Ciênc Cuid Saúde [internet] 2005; [acesso 10 set 2009];4(2):163-70. Disponível em: http://www. periodicos.uem.br/ojs/index.php/CiencCuidSaude/ article/viewPDFInterstitial/5229/3371

19. Morin E. Os sete saberes necessários à educação do futuro. 9.ed. São Paulo: Cortez; Brasília, DF: UNESCO; 2004.

20. Morin E. O método. A natureza da natureza. 3.ed. Lisboa (PT): Publicações Europa-América; 1997.

21. Pombo O. Interdisciplinaridade: ambições e limites. Viseu (PT): Relógio D’Água Editores; 2004.

22. Watson J. Nursing: the philosophy and science of caring / Jean Watson. Colorado (US): University Press of Colorado; 2008.

23. Mitre SM, Siqueira-Batista R, Girardi-de-Mendonça JM, Morais-Pinto NM, Meirelles CAB, Pinto-Porto C, et al. Metodologias ativas de ensino-aprendizagem na formação profissional em saúde: debates atuais. Ciênc. Saúde Col. 2008;13(Suppl.2):2133-44.
Received: May $12^{\text {th }} 2010$ Accepted: Jan. $7^{\text {th }} 2011$ 